Ryszard Pujszo ${ }^{1}$, Mirosław Smaruj ${ }^{2}$, Błach Wiesław $^{3}$

${ }^{1}$ Physical Education and Sports Studies, Uniwersity of Kazimierz Wielki in Bydgoszcz

${ }^{2}$ Physical Education and Sports Academy in Gdańsk

${ }^{3}$ Methodology and Sport Disciplines Department, Physical Education Academy in Wrocław

Corresponding author ; Ryszard Pujszo Ph.D. Uniwersity of Kazimierz Wielki 85064 Bydgoszcz

ul Chodkiewicza 30.p 031.

e-mail:swfis@ukw.edu.pl

private e- mail: rychu54@interia.pl

\title{
The Crampton`s index and the body postural control of judo competitors
}

\begin{abstract}
Aim: The system of body postural control is very important in combat sports and the aim of intensive research. In combat judo is often rapid change of the body from the recumbent to standing position. It was decided to see if it is related to body postural control of judo players Material and methods: The 23 judo players were examined by Crampton's test, and next were tested the level of the body balance on a standard posturography platform

Results: Judo players with low Cramptons indicator showed a negative correlation with the level of body postural control disorders

Conclusions: The selected correlation among the judo training, Crampton`s indicator, and cardiovascular reaction to the change of body position from horizontal to vertical has been observed.
\end{abstract}

\section{Key words}

Crampton's index, equilibrium disorders rate, blood pressure 


\section{Introduction}

The system of body postural control is the aim of intensive research (1). One of the ways to examine it, is to analyze the human center of pressure. To the recording of the movement, trajectory devices which measure the place of the center of pressure as a posturograph or balance platform are used. It is known that many factors both interior and exterior as: temporal loss of body postural control [2], tiredness [3], nervousness, outside temperature and many others is important in the system's proper work [4,5]. It is also proved that longlasting training with many elements disturbing the equilibrium, results in the improvement of the control of the body position [6].

The Crampton's test is the orthostatic test determining the adaptation of blood circulation system while the changes of the body position from the recumbent to standing, taking into consideration the frequency of the heart rate and the systolic blood pressure (SBP). The change of the position from recumbent to standing causes the dislocation of large amounts of blood to the lower parts of the body. In the physiological conditions the changes of the blood pressure and the blood capacity in the blood vessel are analyzed by bar-receptors (receptors responsible for the control of the blood pressure). Bar-receptors send the messages to the central nervous system and by that the organism gets the control over the blood pressure.

It is considered that the functional state of bar-receptors and the cardiac output have a meaningful influence on the orthostatic tolerance. The reason of orthostatic disorders while the change of the body position can be both the insufficient increase of the heart rate and the insufficient increase of the systolic blood pressure (SBP), the lack of change in SBP but mainly the decrease of it [7].

Incorrect organism's reaction can show the orthostatic hypotony evoked by the incorrect functioning of the autonomy system (the central nervous system). The ortostatic hypotony is the decrease of systolic blood pressure more than $20 \mathrm{mmHg}$ (or the systolic blood pressure DBP for more than $10 \mathrm{mmHg}) 3$ minutes after verticalization. The symptoms of orthostatic hypotony are, above all, headaches and disorders of the control of the body position [5].

While the examinations, it was a matter of deliberation if the long-lasting training can influence the results in orthostatic test described by the Crampton's index (ICR) and if there is a dependence between that index and the control of the body position.

Judo competitors were the examined group as the judo fight is very complex and can take place in nage waza (standing position) and katame waza (on the mat). The throws are divided into groups: hand throwing techniques (te waza), foot throwing techniques (ashi waza), hip 
throwing techniques (koshi waza) and sacrifice techniques (sutemi waza). The grips are divided into pins or mathold (osaekomi waza), chokes or strangles (shime waza) and arm locks (kansetsu waza).

One correctly used technique can finish the fight before the statutory time and provide the victory to the competitor who used the technique, despite the fight result so far.

While the fight in this sport discipline, the frequent and sudden changes of the body position occur. These changes are always accompanied by blood circulation reactions which always change the heart rates and the systole pressure.

Incorrect reactions of the blood circulation system can be dangerous to health and security of a competitor with the symptoms of nausea, dizziness and the general worsen of the body balance $[7,8]$.

The ability to keep the body balance enables to keep the balanced position of the body and preservation or gaining of the mentioned state while the physical activity or directly after it.

The basis to the body balance preservation are the main information from the touch, kinesthetic, optical and atrial analyzer [9].

The regulation of the body balance occurs in the nervous system and it is determined by its activity. However, the mechanisms of the control of the body balance are not well known so far [10].

Taking into consideration that Crampton's index defines the adapting ability of the blood circulation system while changing the body position and the significance of the activity to preserve the body balance while the judo fight, it has been noticed that the peculiarity of the judo training has a positive influence on the value of the Crampton's index among the judo competitors and may be a base for the future profile of the master competitor [11].

\section{Material and methods}

In July 2008, 23 judo competitors took part in the examination taken up on judo meetings in Janowo Lubelskie, Sępólno Krajeńskie and Gdańsk.

The examination consisting of the Crampton's test and the body balance disrupt test were taken in the morning (10-12 a.m.). Firstly, the Crampton's test was taken (the measurement of the heart rate and the systole pressure after 10 minutes of recumbent). Secondly, the examined competitor stood up and after 2 minutes the heart rate and the systole pressure were measured again. 
The level of the body balance was established with the use of the posturograph. The measurement was based on the recording of the center of pressure (C.O.P) on the specific platform for 32 seconds and the results were received in the statokinesiogram graph [12].

The developed figure surface of statokinezjogram was taken into analyze as it is commonly known that the highest values this parameter gets the worst the control of the body position is $[6,13]$.

Directly after the Crampton's test the level of the body balance was estimated. Next the examined competitor did six somersaults by the left shoulder to the standing position in the time of 18 seconds and the body balance was estimated again $[3,6,12]$.

The examinations were taken in a large closed ventilated room with the inside temperature of about $22^{\circ} \mathrm{C}$.

The changes in the work of the control of the body position system were described with the developed figure surface of a statokinesiogram.

$\mathrm{S}_{0}$ - the figure surface in a standing position $\left[\mathrm{mm}^{2}\right]$,

$\mathrm{S}_{1}-$ the figure surface after disturbed by the somersaults $\left[\mathrm{mm}^{2}\right]$.

There was also the relative figure surface of the statokinesiogram. estimated (further called as a level of the body balance disorders) $\mathrm{Z}_{1}\left[\mathrm{~mm}^{2}\right]$ :

$$
Z_{1}=\frac{S_{1}-S_{0}}{S_{0}}
$$

The Crampton's index (ICR) was estimated from the formula:

$$
\mathrm{ICR}=25 \mathrm{x}(3.15+\mathrm{DTA}-\mathrm{DPS}: 20)
$$

DTA - the difference of the systole of the blood pressure [ $\mathrm{cm} \mathrm{Hg}$ ]

DPS - the difference of the frequency of the heart rates [mm $\mathrm{Hg}$ ]

pressure $1=$ the recumbent position

pressure $2=$ the standing position 
The results were worked out in a statistic methods with the use of Statistic (version5.0). The basic anthropometric data of the examined group are presented in Table 1.

Table 1. Anthropometric data of the examined competitors.

\begin{tabular}{lllllllll}
\hline $\begin{array}{l}\text { Number } \\
\text { of }\end{array}$ & AGE & RANGE & HEIGHT & $\begin{array}{l}\text { RANGE } \\
(\mathrm{m})\end{array}$ & $\begin{array}{l}\text { WEIGHT } \\
(\mathrm{kg})\end{array}$ & $\begin{array}{l}\text { RANGE } \\
(\mathrm{kg})\end{array}$ & $\begin{array}{l}\text { BMI } \\
\left(\mathrm{kg} / \mathrm{m}^{2}\right)\end{array}$ & $\begin{array}{l}\text { RANGE } \\
\left(\mathrm{kg} / \mathrm{m}^{2}\right)\end{array}$ \\
$\begin{array}{l}\text { competit } \\
\text { ors }\end{array}$ & & & & & & & & \\
\hline $\mathrm{n}=23$ & $17,50 \pm 1,92$ & $13,5-22$ & $1,76 \pm 0,07$ & $1,63-1,92$ & $75,73 \pm 12,97$ & $54,5-97$ & $24,5 \pm 3,3$ & $19,1-31$ \\
\end{tabular}

\section{Results}

Table 2 presents the average values of the measurement of the statokinesiogram. figure surface in a standing position $\left(\mathrm{S}_{0}\right)$ and the values disturbed by the somersaults $\left(\mathrm{S}_{1}\right)$ and the average value of the level of the disturbance of the control of the body position $\left(\mathrm{Z}_{1}\right)$, DTA value, DPS value and the average value of ICR.

Table 2. The results of measurements in the body balance disorders test and in the Crampton's test.

\begin{tabular}{lllllll}
\hline $\begin{array}{l}\text { Number } \\
\text { of compet. }\end{array}$ & $\mathrm{S}_{0}$ & $\mathrm{~S}_{1}$ & $\mathrm{Z}_{1}$ & DTA & DPS & ICR \\
& & & & & \\
& & & & & \\
\hline \multicolumn{1}{c}{} & & & & & \\
$\mathrm{n}=23$ & 189,8 & 300,65 & 0,65 & 0,67 & 10,9 & $81,9 \pm 3,95$ \\
& \pm & \pm & \pm & \pm & \pm & \\
& $76,1^{*}$ & $136,1^{*}$ & 0,62 & 0,18 & 7,3 & \\
\hline
\end{tabular}

* the differences statistically important on the level of $p<0,05$. 
Picture 1 present's the values of ICR factor depending on the changes of the value of the systole pressure after the change of the body position from the recumbent to the standing position.

Picture 2 presents the values of ICR factor depending on the changes of the frequency of the heart rates after the change of the body position from the recumbent to standing position.

Picture 1 The changes of the values of the Crampton's index (ICR) depending on the changes of the value of the systole pressure after the change of the body position from the recumbent to the standing position.

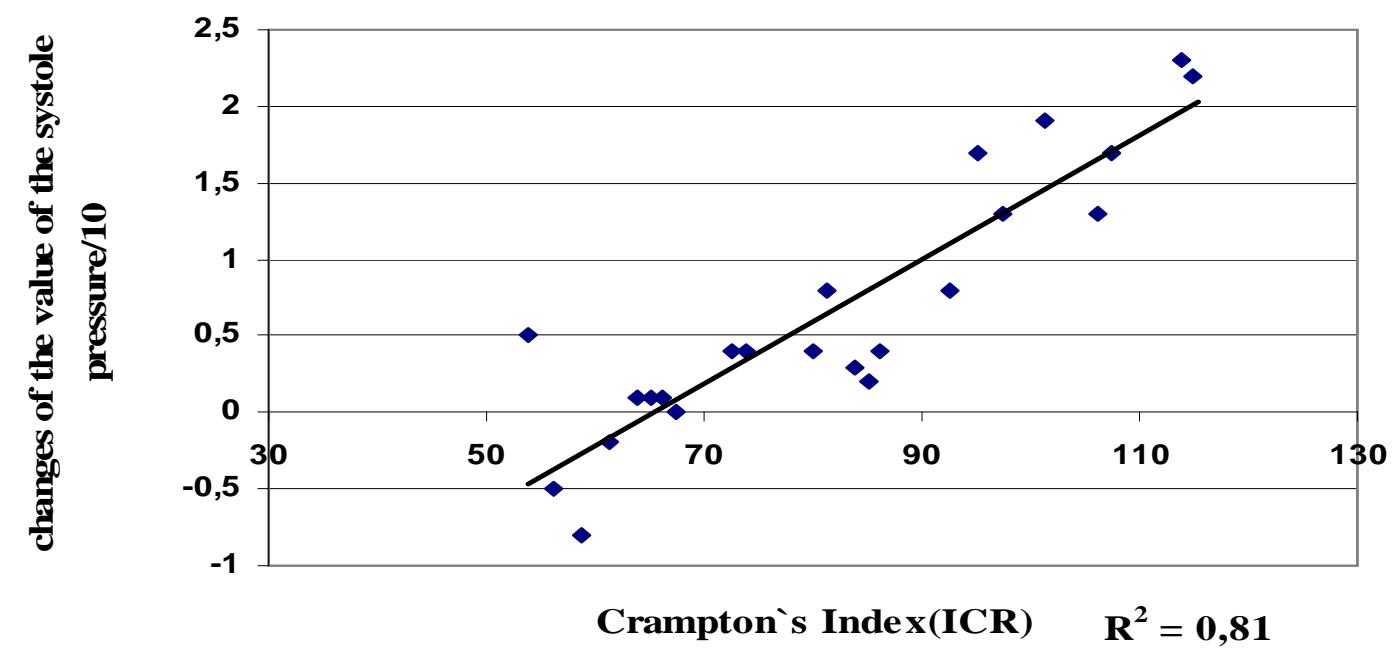

The relationship between the variables presented on the graph is high $\left(\mathbf{R}^{\mathbf{2}}=\mathbf{0 8 1}\right)$ 
Picture. 2 The changes of the value of the Crampton's index (ICR) depending on the changes of the value of the heart rates after the change of the body position from the recumbent to the standing position.
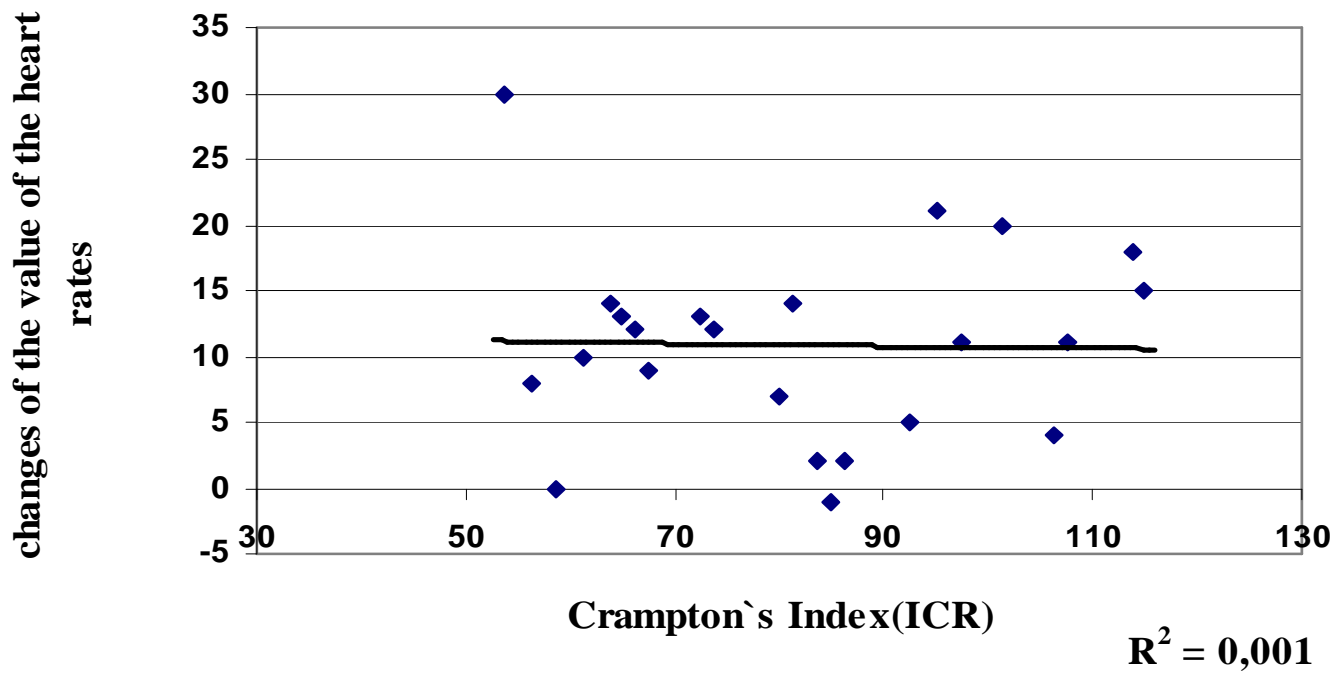

The relationship between the variables was not observed $\left(\mathbf{R}^{\mathbf{2}}=\mathbf{0 , 0 0 1}\right)$.

Picture 3 presents the changes in the value of the level of the body balance disorders $Z_{1}$ depending on the value of the ICR index.

Picture 3 The changes in the value of the level of the body balance disorders $Z_{1}$ depending on the value of the ICR index.

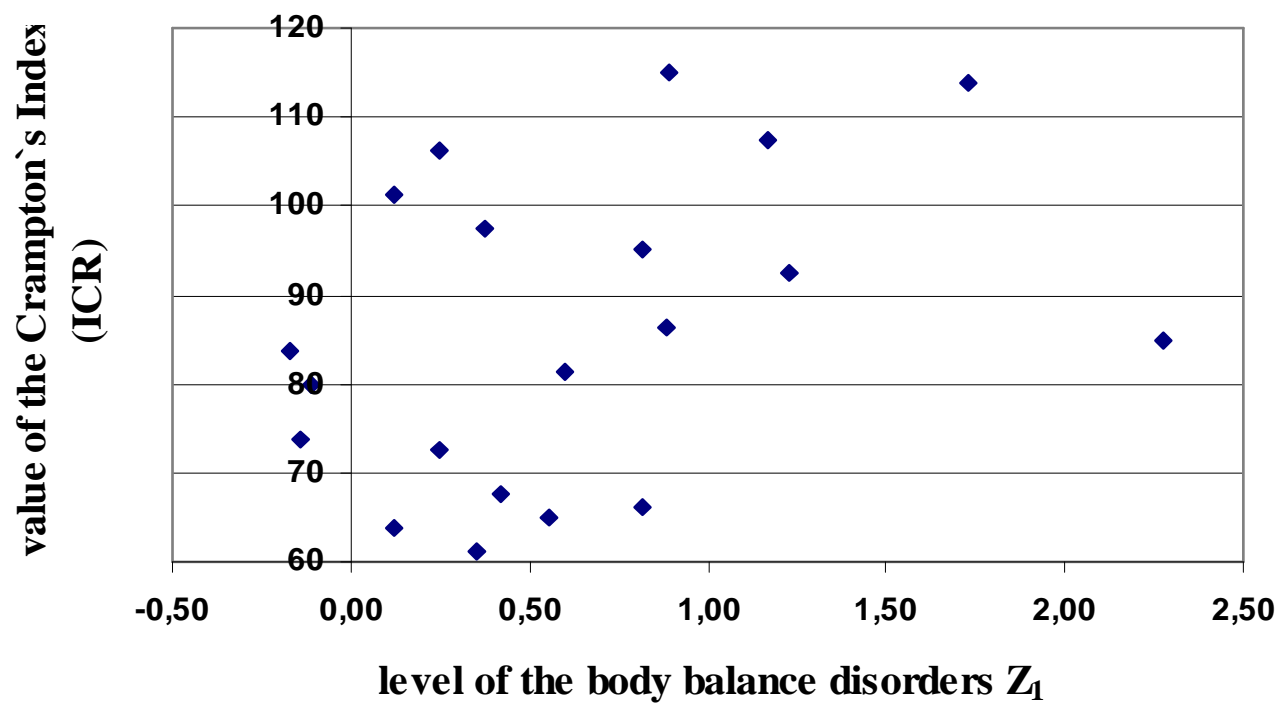

The graph presents the lack of relationship between the variables $(\mathbf{R}=\mathbf{0 , 0 0 1})$. 
The graph presented in Picture 3 was given to further analyses and separated the variables as a criterion applying the value of the Crampton's index (ICR) $=80$ (it is the value of the index defined as sufficient).

The results gained after the division were presented in Table 3 and 4 and on graphs 4 and 5 .

Group 1 consists of competitors who gained the ICR value lower or equal 80.

Group 2 consists of competitors who gained the value above 80 .

Table 3. The results of measures in the body balance disorder test and the Crampton's test for group 1 after the division of the variables.

\begin{tabular}{cccccccc}
\hline $\begin{array}{l}\text { Number of } \\
\text { competitors } \\
\text { group1 }\end{array}$ & pulse 1 & pulse 2 & DPS & $\begin{array}{l}\text { pressure1 } \\
(\mathrm{mmHg})\end{array}$ & $\begin{array}{l}\text { pressure2 } \\
(\mathrm{mmHg})\end{array}$ & $\begin{array}{l}\text { DTA } \\
(\mathrm{cmHg})\end{array}$ & ICR \\
\hline & & & & & & & \\
$\mathrm{n}=11$ & $66,2 \pm 7,5$ & $\begin{array}{l}77,8 \pm \\
12,1\end{array}$ & $11,6 \pm 7,3$ & $\begin{array}{l}127,7 \pm \\
16,0^{*}\end{array}$ & $\begin{array}{l}128,2 \pm \\
15,1\end{array}$ & $\begin{array}{l}0,05 \pm \\
0,41^{*}\end{array}$ & $\begin{array}{l}* \\
\end{array}$ \\
& & & & & & & \\
\hline
\end{tabular}

Table 4. The results of measures in the body balance disorder test and the Crampton's test for group 2 after the division of the variables.

\begin{tabular}{ccccllll}
\hline $\begin{array}{l}\text { Number of } \\
\text { competitors } \\
\text { group2 }\end{array}$ & pulse 1 & pulse 2 & DPS & $\begin{array}{l}\text { pressure1 } \\
(\mathrm{mmHg})\end{array}$ & $\begin{array}{l}\text { pressure2 } \\
(\mathrm{mmHg})\end{array}$ & $\begin{array}{l}\text { DTA } \\
(\mathrm{cmHg})\end{array}$ & ICR \\
\hline \multirow{2}{*}{$\mathrm{n}=12$} & $66,9 \pm$ & $77,1 \pm$ & $10,2 \pm 7,6$ & $112,8 \pm$ & $125,2 \pm$ & $1,24 \pm$ & $97,12 \pm$ \\
& 12,9 & 10,8 & & $16,9^{*}$ & 20,6 & $0,74^{*}$ & $11,8 *$ \\
\hline
\end{tabular}

\footnotetext{
* the differences statistically meaningful for the values of the same columns of Table 3 and 4 on the level of $\mathrm{p}<0,05$
}

Picture 4 presents the changes of the level of the body balance disorders $Z_{1}$ depending on the value of the Crampton's index (ICR) for group 1 after the division of the variables.

Picture 5 presents the changes of the level of the body balance disorders $Z_{1}$ depending on the value of the Crampton's index (ICR) for group 2 after the division of the variables. 
Picture 4 . The changes of the level of the body balance disorders $Z_{1}$ depending on the value of the Crampton's index (ICR) for group 1 after the division of the variables.

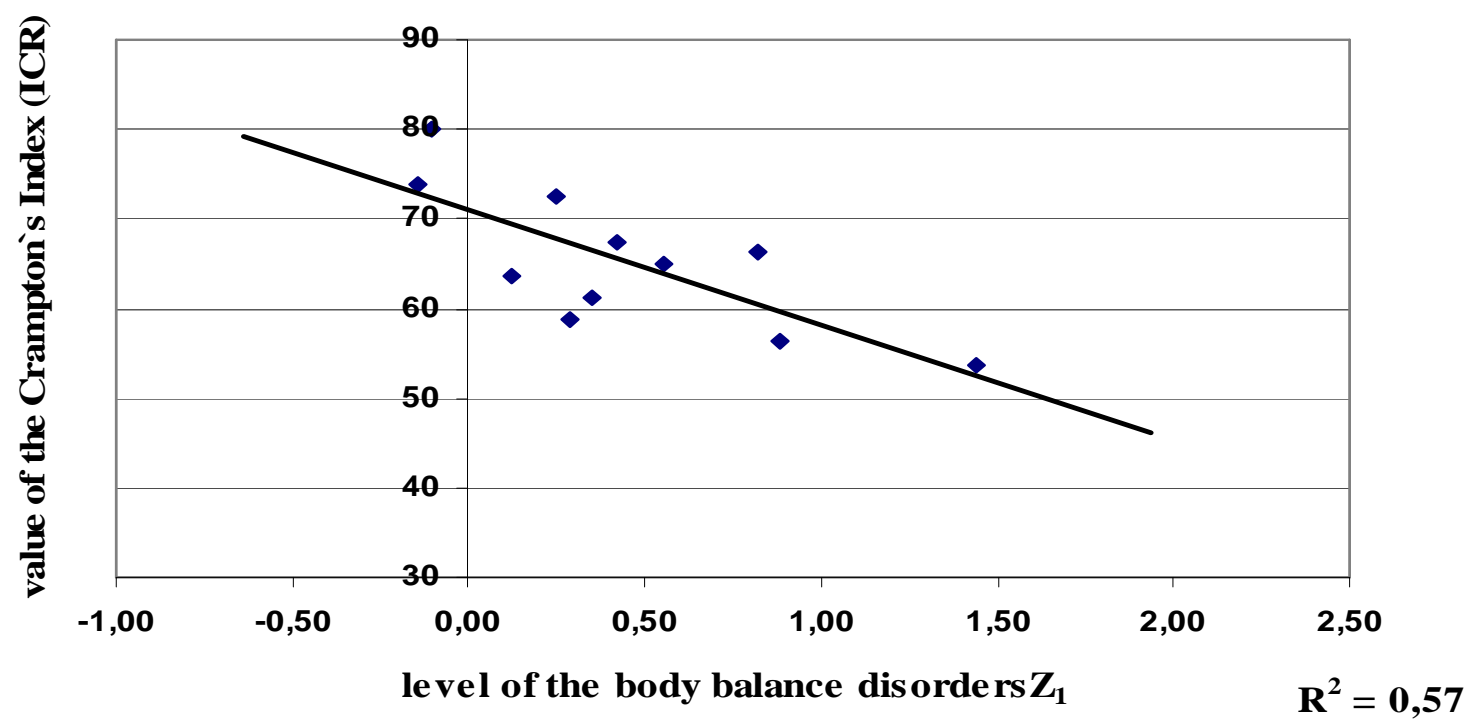

The values presented on the graph show the high relationship between the variables $\left(\mathbf{R}^{\mathbf{2}}=\mathbf{0 , 5 7}\right)$

Picture 5 The changes of the level of the body balance disorders $Z_{1}$ depending on the value of the Crampton's index (ICR) for group 2 after the division of the variables.

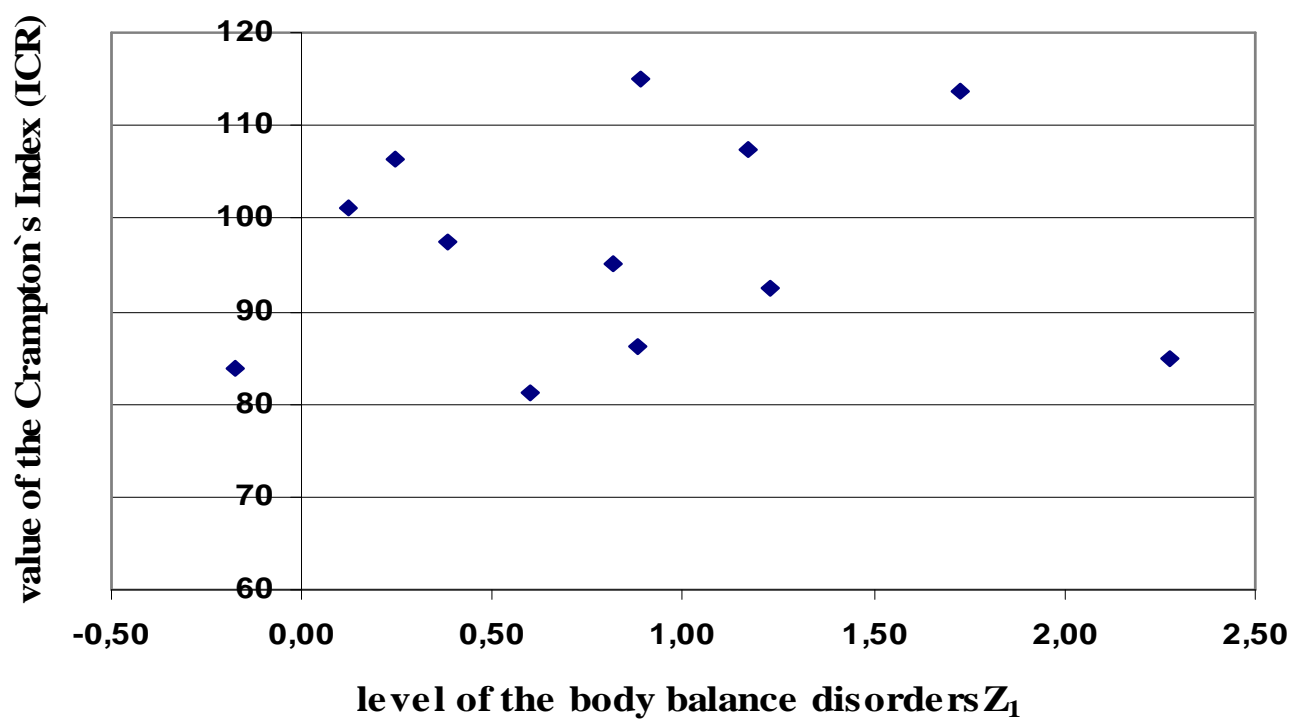

There were no changes between the variables observed. 
Picture 6 The changes in the value of the body balance disorders $Z_{1}$ depending on the changes of the body height among all competitors.

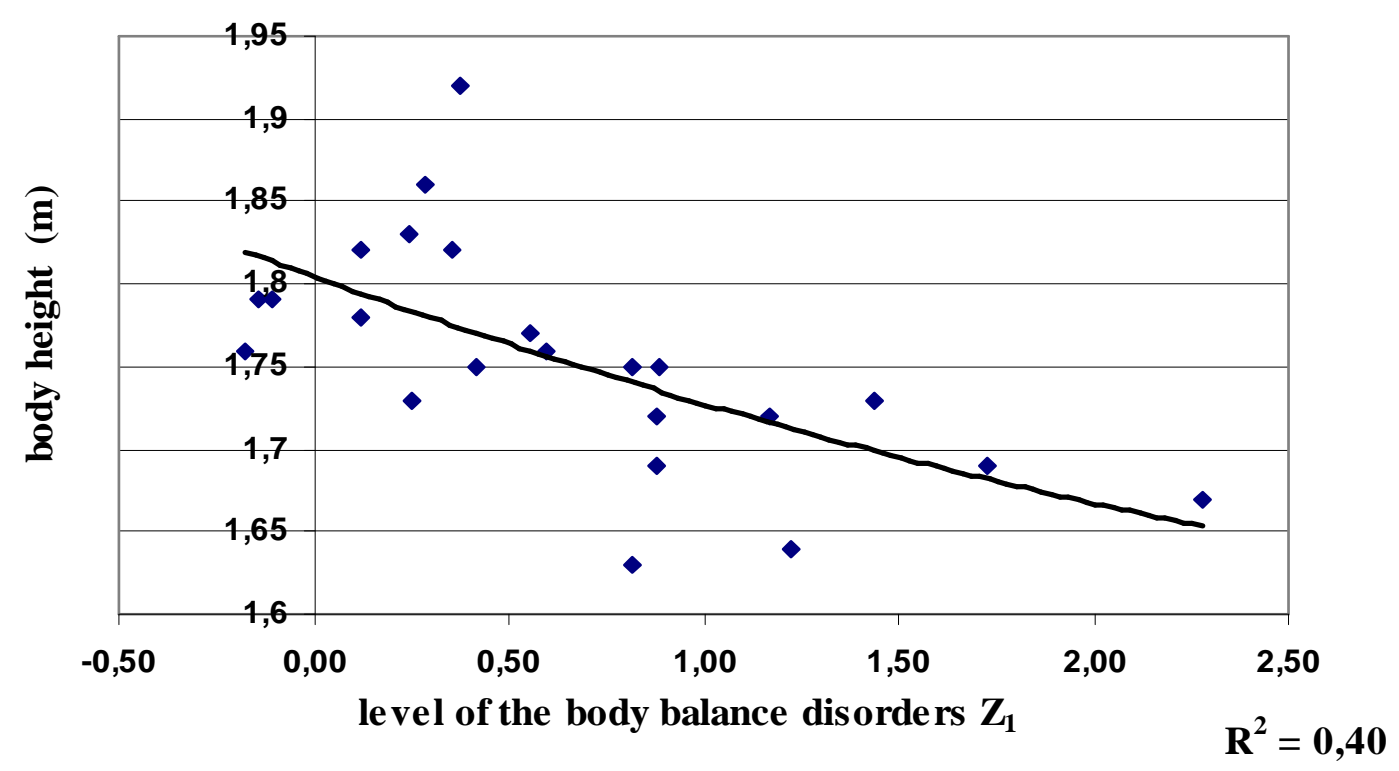

The relationship between the variables is statistically important $\left(\mathbf{R}^{\mathbf{2}}=\mathbf{0 , 4 0}\right)$

The higher competitors are observed to have lower body balance disorders in the test of six somersaults. The above statistically important relationship $\mathbf{R}^{\mathbf{2}}=\mathbf{0 , 4 0}$ is surprising and so far it was not confirmed in literature on the body balance both among male population and judo competitors.

The introduction analyses of the results gained in the examination show that:

- the statistically meaningful relationship between the change of the Crampton's index and the change of the body position disorder exists, but there is no relationship between the value of the Crampton's index (ICR) and the change of the pulse value after the change for recumbent to standing position.

- There was no meaningful relationship between the change of the value of the body balance disorder $\mathrm{Z}_{1}$ and the value of the Crampton's index (ICR) after the change from recumbent to standing position among the competitors in the examined group. The relationship was present after the division of the examined group into two smaller groups.

- The data presented in Tables 3 and 4 shows that the competitors with the higher (better) Crampton's index (ICR) were reacting to the change of the body position from 
recumbent to standing position with the meaningful increase of the systole pressure and the frequency of the heart rates. The competitors with lower Crampton's index (ICR) were only reacting with the increase of frequency of the heart rates.

\section{Discussion}

The proper control of the body postural stability is necessary in many sport disciplines (gymnastics, jumps, aviation and martial arts) and is also crucial in everyday life for safe functioning of the whole human body $[4,6,13,14]$. Also has a relationship with human concentration and effect of "placebo"[15]. The disturbs in the system of the body position control can take place in many ways. The most common of these ways is the disturbance in the labyrinth balance after the rotary movement with the minimum speed of 0,8 Radian/sec [7].

The examinations taken up on people who are training sports containing many stimulating disturbances of the body balance show that human organism becomes immune on those disturbances and it means that the organism undergoes a classical training.

The phenomenon has been already described among dancers, female judo competitors, bareback riding competitors and even among women training self-defense amateur $[2,3,13,16]$.

Both in judo training and in judo fights it is very frequent for the competitor to change the position from recumbent or kneeling to standing and continuing the physical effort after this change. In judo there are also the situations of passive lying down and next the change to the standing position and continuing the training and the fight.

In the examinations the judo competitors were reacting to the change of the body position (from recumbent to standing) with te increase of the systole pressure and the rise of the value of the frequency of the heart rates on a good level (according to the Crampton's norms).

There were no dangers of orthostatic hypotony observed. The gained results are similar to the results gained for judo competitors in different age group, though they are a bit lower [5].

The Crampton's index (ICR) showed positive, statistically meaningful relationship with the increase of the systole pressure but there was no connection with the increase of frequency of the heart rates, that is why the pressure reaction may be perceived as the decising when it comes to the Crampton's index (ICR). 
The index of the body balance $Z_{1}$ did not present any statistically important connection with the Crampton's index (ICR) and the scattering points presented on the graph on Picture 3 suggested the analyze and the separation of the variables.

After the separation of the results it appeared that the competitors of group1 (the ICR value lower or equal 80) reacted for the change of the body position from recumbent to standing position only with the increase of frequency of the heart rates. The competitors in group 2 (ICR value more than 80) reacted with the increase of both the frequency of the heart rates and the value of the systole pressure (Table 3 and 4 ).

Analyzing the relationship between the Crampton's index (ICR) and the index of the body balance disorders $\mathrm{Z}_{1}$ in both groups, it can be noticed that in group 1 there is negative, statistically important relationship $\mathrm{R}^{2}=0,57$ but in group 2 there is no such a relationship (Picture 4 and 5).

The examination results allow to formulate the following observation, except the results of the examination about the group separation because of the number of competitors in the group thus the examination should be proved in further examinations on the issue.

Summing:

1. The judo competitors' reaction for the change of the body position from recumbent to standing was correct.

2. There was no single case suggesting hypotony.

3. There was no relationship between the Crampton's index (ICR) and the body balance disorder index $Z_{1}$ in the examined group with the high Crampton's index.

4. There is a meaningful relationship between the organism reaction for the recumbent to standing position and the level of the body balance (the lower ICR index value, the lower body balance level) among judo competitors with the low Crampton's index level. However, this statement should be proved in further examination on the issue.

5. The statistically important relationship between the competitors' height and the level of balance directly after the six somersaults was found. 


\section{Conclusions}

1. The observations presented in section 1 and 2 of the summary shows that judo training has a positive correlation with the adaptation of the cardiovascular system during the change of position of the body - from lying down to standing described by Crampton indicator.

2. The observations presented in section 3 and 4 of the summary shows that the reaction of body postural control has a negative correlation with the cardiovascular response during postural changes - from horizontal to vertical position only in judo athletes with a low or middle Cramton`s indicator (ICR <80) - such as in people not practicing.

In judo athletes with higher level of Crampton`s indicator (ICR>.80) both systems react separately.

\section{References}

1. Colins J.J., De Luca C.J. [1993]: Open-loop and closed-loop control of posture: random-walk analysis of center-of-pressure trajectories. Expromental brain research, 1993, vol. 95, 308-318.

2. Błach W. [2001]: Amplituda maksymalnych swobodnych wychyleń ciała zawodników dżudo i studentów AWF w płaszczyźnie strzałkowej. Człowiek i Ruch - Human Movement 2001, nr 2(4), 82-86.

3. Błach W., Pujszo R., Pyskir M., Adam M. Kontrola postawy ciała zawodniczek judo Research Yearbook 2005;11:30-6.

4. Błaszczyk J. W., Lowe D. L., Hansen P. D. [1994]: Ranges of postural stability and their changes in the elderly. Gait \& Posture, vol. 2, 11-17.

5. Winter D. A. [1995]: Human balance and posture control during standing and walking. Gait \& Posture 1995, vol. 3, 193-214.

6. Bosek M, Pujszo R, Pyskir M, Grzegorzewski B, Błach W. [2004]: Wpływ wybranych ćwiczeń fizycznych na system kontroli postawy człowieka. Medycyna Sportowa vol. 20 , nr 5, 247-253.

7. Ganong W.F. [1994]: Podstawy fizjologii lekarskiej. PZWL, Warszawa.

8. Kozłowski S. [1952]: Wpływ pozycji ciała na czynność narządu krążenia i oddychania. Acta Physiol. Pol. 
9. Raczek J., Mynarski W., Ljach W. [2003]: Kształtowanie i diagnozowanie koordynacyjnych zdolności motorycznych. Akademia Wychowania Fizycznego w Katowicach.

10. Juras G. [2003]: Koordynacyjne uwarunkowania procesu uczenia się utrzymywania równowagi ciała. Akademia Wychowania Fizycznego w Katowicach.

11. Adam M., Smaruj M., Pujszo R.(2012)" The individual profile of the technicaltactical preparation of the World judo Championships in 2010-2011" "Ido Movement For Culture. Journal of Martial Arts Anthropology", Vol. 12, no. 2 (2012), pp. 50-59

12. Kubiczkowa J. [1998]: Rola posturografii w medycynie lotniczej. Medycyna Lotnicza, 1998, nr 3, 301-309.

13. Kochanowicz K., Taniewski M. [1999]: Badanie układu równowagi młodocianych gimnastyków. Sport Wyczynowy 1999, nr 5-6.

14. Perrin P., Deviterne D., Hegel F., Perrot C. [2002]: Judo, better than dance, develops sensorimotor adaptabilities involved in balance control. Gait and Posture, 2002 vol. 15, 187-194.

15. Pujszo R. Skorupa H, Smaruj M, Sybilski Z, Wolska B. [2006]: Koncentracja uwagi i efekt placebo w kontroli postawy ciała W: Człowiek - jego bioelektroniczna konstrukcja a percepcja muzyki. Praca zbiorowa pod red. Adama Adamskiego. Kęty,

16. Perrot C., Deviterne D., Perrin Ph. P. [1998]: Influence of training on postural and motor control in a combative sport. Journal Human Movement Studies, vol. 35, 119136. 